\title{
Tachykinin receptors (version 2019.4) in the IUPHAR/BPS Guide to Pharmacology Database
}

\author{
Jeffrey Barrett ${ }^{1}$, Brenden Canning ${ }^{2}$, Joseph Coulson ${ }^{3}$, Erin Dombrowsky ${ }^{1}$, Steven D. Douglas ${ }^{4}$, Tung M. Fong ${ }^{5}$, \\ Christa Y. Heyward ${ }^{1}$, Susan E. Leeman ${ }^{6}$ and Pranela Remeshwar ${ }^{7}$ \\ 1. Children's Hospital of Philadelphia, USA \\ 2. Johns Hopkins, USA \\ 3. University of Edinburgh, UK \\ 4. University of Pennsylvania, USA \\ 5. Covance Inc, USA \\ 6. Boston University, USA \\ 7. University of Medicine and Dentistry of New Jersey, USA
}

\begin{abstract}
Tachykinin receptors (provisional nomenclature as recommended by NC-IUPHAR [90]) are activated by the endogenous peptides substance $\mathrm{P}(\mathrm{SP})$, neurokinin $\mathrm{A}$ (NKA; previously known as substance $\mathrm{K}$, neurokinin $\alpha$, neuromedin $L$ ), neurokinin $B$ (NKB; previously known as neurokinin $\beta$, neuromedin $K$ ), neuropeptide $K$ and neuropeptide $Y$ (N-terminally extended forms of neurokinin $A$ ). The neurokinins ( $A$ and $B$ ) are mammalian members of the tachykinin family, which includes peptides of mammalian and nonmammalian origin containing the consensus sequence: Phe-x-Gly-Leu-Met. Marked species differences in in vitro pharmacology exist for all three receptors, in the context of nonpeptide ligands. Antagonists such as aprepitant and fosaprepitant were approved by FDA and EMA, in combination with other antiemetic agents, for the prevention of nausea and vomiting associated with emetogenic cancer chemotherapy.
\end{abstract}

\section{Contents}

This is a citation summary for Tachykinin receptors in the Guide to Pharmacology database (GtoPdb). It exists purely as an adjunct to the database to facilitate the recognition of citations to and from the database by citation analyzers. Readers will almost certainly want to visit the relevant sections of the database which are given here under database links.

GtoPdb is an expert-driven guide to pharmacological targets and the substances that act on them. GtoPdb is a reference work which is most usefully represented as an on-line database. As in any publication this work should be appropriately cited, and the papers it cites should also be recognized. This document provides a citation for the relevant parts of the database, and also provides a reference list for the research cited by those parts.

Please note that the database version for the citations given in GtoPdb are to the most recent preceding version in which the family or its subfamilies and targets were substantially changed. The links below are to the current version. If you need to consult the cited version, rather than the most recent version, please contact the GtoPdb curators. 


\section{Database links}

Tachykinin receptors

http://www.guidetopharmacology.org/GRAC/FamilyDisplayForward?familyld=62

Introduction to Tachykinin receptors

http://www.guidetopharmacology.org/GRAC/FamilyIntroductionForward?familyld=62

Receptors

$\mathrm{NK}_{1}$ receptor

http://www.guidetopharmacology.org/GRAC/ObjectDisplayForward?objectld=360

$\mathrm{NK}_{2}$ receptor

http://www.guidetopharmacology.org/GRAC/ObjectDisplayForward?objectld=361

$\mathrm{NK}_{3}$ receptor

http://www.guidetopharmacology.org/GRAC/ObjectDisplayForward?objectld=362

\section{References}

1. Abdel-Gawad M, Dion SB and Elhilali MM. (2001) Evidence of a peripheral role of neurokinins in detrusor hyperreflexia: a further study of selective tachykinin antagonists in chronic spinal injured rats. J. Urol. 165: 1739-44 [PMID:11342967]

2. Abelli L, Somma V, Maggi CA, Regoli D, Astolfi M, Parlani M, Rovero P, Conte B and Meli A. (1989) Effects of tachykinins and selective tachykinin receptor agonists on vascular permeability in the rat lower urinary tract: evidence for the involvement of NK-1 receptors. J Auton Pharmaco/ 9: 253-63 [PMID:2475507]

3. Aharony D, Buckner CK, Ellis JL, Ghanekar SV, Graham A, Kays JS, Little J, Meeker S, Miller SC and Undem BJ. (1995) Pharmacological characterization of a new class of nonpeptide neurokinin A antagonists that demonstrate species selectivity. J. Pharmacol. Exp. Ther. 274: 1216-21 [PMID:7562491]

4. Ahluwalia A, De Felipe C, O'Brien J, Hunt SP and Perretti M. (1998) Impaired IL-1beta-induced neutrophil accumulation in tachykinin NK1 receptor knockout mice. Br. J. Pharmacol. 124: 1013-5 [PMID:9720767]

5. Altamura M. (2012) Tachykinin NK2 receptor antagonists. A patent review (2006 - 2010) Expert Opin Ther Pat 22: 57-77 [PMID:22149761]

6. Altier N and Stewart J. (1997) Tachykinin NK-1 and NK-3 selective agonists induce analgesia in the formalin test for tonic pain following intra-VTA or intra-accumbens microinfusions. Behav. Brain Res. 89: 151-65 [PMID:9475623]

7. Amegadzie AK, Gardinier KM, Hembre EJ, Hong JE, Jungenheim LN, Muehl BS, Remick DM, Robertson MA and Savin KA. (2003) Triazole derivatives as tachykinin receptor antagonists Patent number: WO2003091226.

8. Andrews PV, Helme RD and Thomas KL. (1989) NK-1 receptor mediation of neurogenic plasma extravasation in rat skin. Br. J. Pharmacol. 97: 1232-8 [PMID:2477105]

9. Anthes JC, Chapman RW, Richard C, Eckel S, Corboz M, Hey JA, Fernandez X, Greenfeder S, McLeod R and Sehring S et al.. (2002) SCH 206272: a potent, orally active tachykinin NK(1), NK(2), and NK(3) receptor antagonist. Eur. J. Pharmacol. 450: 191-202 [PMID:12206858]

10. Arck PC, Handjiski B, Kuhlmei A, Peters EM, Knackstedt M, Peter A, Hunt SP, Klapp BF and Paus R. (2005) Mast cell deficient and neurokinin-1 receptor knockout mice are protected from stress-induced hair growth inhibition. J. Mol. Med. 83: 386-96 [PMID:15759104]

11. AstraZeneca. AZD2624.

12. Bahouth SW and Musacchio JM. (1985) Specific binding of [3H]substance $P$ to the rat submaxillary gland. The effects of ions and guanine nucleotides. J. Pharmacol. Exp. Ther. 234: 326-36 [PMID:2410593]

13. Barbieri M and Nistri A. (2001) Depression of windup of spinal neurons in the neonatal rat spinal cord in vitro by an NK3 tachykinin receptor antagonist. J Neurophysio/ 85: 1502-1511 [PMID:11287474]

14. Barr AJ, Watson SP, Bernal AL and Nimmo AJ. (1991) The presence of NK3 tachykinin receptors on rat uterus. Eur. J. Pharmacol. 203: 287-90 [PMID:1724757] 
15. Bayguinov O, Hagen B and Sanders KM. (2003) Substance P modulates localized calcium transients and membrane current responses in murine colonic myocytes. Br. J. Pharmacol. 138: 1233-43 [PMID:12711623]

16. Beaujouan JC, Saffroy M, Torrens Y and Glowinski J. (1997) Potency and selectivity of the tachykinin NK3 receptor antagonist SR 142801. Eur. J. Pharmacol. 319: 307-16 [PMID:9042606]

17. Bellucci F, Carini F, Catalani C, Cucchi P, Lecci A, Meini S, Patacchini R, Quartara L, Ricci R and Tramontana M et al.. (2002) Pharmacological profile of the novel mammalian tachykinin, hemokinin 1.Br. J. Pharmacol. 135: 266-74 [PMID:11786503]

18. Bennacef I, Tymciu S, Dhilly M, Lasne MC, Debruyne D, Perrio C and Barré L. (2004) Synthesis and biological evaluation of novel fluoro and iodo quinoline carboxamides as potential ligands of NK-3 receptors for in vivo imaging studies. Bioorg Med Chem 12: 4533-4541 [PMID:15265501]

19. Bensaid M, Faucheux BA, Hirsch E, Agid Y, Soubrié $P$ and Oury-Donat F. (2001) Expression of tachykinin NK2 receptor mRNA in human brain. Neurosci. Lett. 303: 25-8 [PMID:11297815]

20. Beresford IJ, Sheldrick RL, Ball DI, Turpin MP, Walsh DM, Hawcock AB, Coleman RA, Hagan RM and Tyers MB. (1995) GR159897, a potent non-peptide antagonist at tachykinin NK2 receptors. Eur. J. Pharmacol. 272: 241-8 [PMID:7713168]

21. Blaney FE, Raveglia LF, Artico M, Cavagnera S, Dartois C, Farina C, Grugni M, Gagliardi S, Luttmann MA and Martinelli $M$ et al.. (2001) Stepwise modulation of neurokinin-3 and neurokinin-2 receptor affinity and selectivity in quinoline tachykinin receptor antagonists. J. Med. Chem. 44: 1675-89 [PMID:11356103]

22. Blum AM, Metwali A, Kim-Miller M, Li J, Qadir K, Elliott DE, Lu B, Fabry Z, Gerard N and Weinstock JV. (1999) The substance $P$ receptor is necessary for a normal granulomatous response in murine schistosomiasis mansoni. J. Immunol. 162: 6080-5 [PMID:10229849]

23. Boden P, Eden JM, Hodgson J, Horwell DC, Hughes J, McKnight AT, Lewthwaite RA, Pritchard MC, Raphy $\mathrm{J}$ and Meecham K et al.. (1996) Use of a dipeptide chemical library in the development of nonpeptide tachykinin NK3 receptor selective antagonists. J. Med. Chem. 39: 1664-75 [PMID:8648606]

24. Bradshaw CG, Ceszkowski K, Turcatti G, Beresford IJ and Chollet A. (1994) Synthesis and characterization of selective fluorescent ligands for the neurokinin NK2 receptor. J. Med. Chem. 37: 19915 [PMID:8027981]

25. Broccardo M, Ciotti MT, Linari G, Agostini S, Petrella C, Amadoro G, Severini C and Improta G. (2005) Immunocytochemical distribution of NK-1 and NK-3 tachykinin receptors in isolated pancreatic acini of guinea pigs and rats. Peptides 26: 2351-4 [PMID:15970359]

26. Broccardo M, Improta $G$ and Tabacco A. (1999) Central tachykinin NK3 receptors in the inhibitory action on the rat colonic propulsion of a new tachykinin, PG-KII. Eur. J. Pharmacol. 376: 67-71 [PMID:10440091]

27. Brocco M, Dekeyne A, Mannoury la Cour C, Touzard M, Girardon S, Veiga S, de Nanteuil G, deJong TR, Olivier B and Millan MJ. (2008) Cellular and behavioural profile of the novel, selective neurokinin1 receptor antagonist, vestipitant: a comparison to other agents. Eur Neuropsychopharmacol 18: 729-50 [PMID:18657401]

28. Buell G, Schulz MF, Arkinstall SJ, Maury K, Missotten M, Adami N, Talabot F and Kawashima E. (1992) Molecular characterisation, expression and localisation of human neurokinin-3 receptor. FEBS Lett. 299: 90-5 [PMID:1312036]

29. Caberlotto L, Hurd YL, Murdock P, Wahlin JP, Melotto S, Corsi M and Carletti R. (2003) Neurokinin 1 receptor and relative abundance of the short and long isoforms in the human brain. Eur J Neurosci 17: 1736-1746 [PMID:12752772]

30. Cao T, Gerard NP and Brain SD. (1999) Use of NK(1) knockout mice to analyze substance P-induced edema formation. Am. J. Physiol. 277: R476-81 [PMID:10444554]

31. Carpentier $C$ and Baude A. (1996) Immunocytochemical localisation of NK3 receptors in the dorsal vagal complex of rat. Brain Res. 734: 327-31 [PMID:8896842]

32. Cascieri MA, Macleod AM, Underwood D, Shiao LL, Ber E, Sadowski S, Yu H, Merchant KJ, Swain CJ and Strader CD et al.. (1994) Characterization of the interaction of N-acyl-L-tryptophan benzyl ester neurokinin antagonists with the human neurokinin-1 receptor. J. Biol. Chem. 269: 6587-91 [PMID:7509807] 
33. Castagliuolo I, Riegler M, Pasha A, Nikulasson S, Lu B, Gerard C, Gerard NP and Pothoulakis C. (1998) Neurokinin-1 (NK-1) receptor is required in Clostridium difficile- induced enteritis. J. Clin. Invest. 101: 154750 [PMID:9541482]

34. Castro TA, Cohen MC and Rameshwar P. (2005) The expression of neurokinin-1 and preprotachykinin-1 in breast cancer cells depends on the relative degree of invasive and metastatic potential. Clin. Exp.

Metastasis 22: 621-8 [PMID:16642400]

35. Catalioto RM, Criscuoli M, Cucchi P, Giachetti A, Gianotti D, Giuliani S, Lecci A, Lippi A, Patacchini R and Quartara L et al.. (1998) MEN 11420 (Nepadutant), a novel glycosylated bicyclic peptide tachykinin NK2 receptor antagonist. Br. J. Pharmacol. 123: 81-91 [PMID:9484857]

36. Catalioto RM, Cucchi P, Renzetti AR, Criscuoli M and Maggi CA. (1998) Independent coupling of the human tachykinin NK2 receptor to phospholipases $\mathrm{C}$ and A2 in transfected Chinese hamster ovary cells. Naunyn Schmiedebergs Arch. Pharmacol. 358: 395-403 [PMID:9826060]

37. Cellier E, Barbot L, Regoli D and Couture R. (1997) Cardiovascular and behavioural effects of intracerebroventricularly administered tachykinin NK3 receptor antagonists in the conscious rat. Br. J. Pharmacol. 122: 643-54 [PMID:9375960]

38. Chang VT, Yook $C$ and Rameshwar P. (2013) Synergism between fibronectin and transforming growth factor- $\beta 1$ in the production of substance $P$ in monocytes of patients with myelofibrosis. Leuk. Lymphoma 54: 631-8 [PMID:22906243]

39. Chen $Y$ and Hoover DB. (1995) Autoradiographic localization of NK1 and NK3 tachykinin receptors in rat kidney. Peptides 16: 673-81 [PMID:7479302]

40. Chin FT, Morse CL, Shetty HU and Pike VW.. (2006) Automated radiosynthesis of [18F]SPA-RQ for imaging human brain NK1 receptors with PET. Journal of labelled compounds and radiopharmaceuticals 17-31

41. Choppin A, Groke G, Bringas A, Stepan G and Dillon MP. (2002) Effect of YM-44781, YM-44778 and YM49598, novel tachykinin antagonists, in a drug-induced bladder contraction model. Pharmacology 65: 96102 [PMID:11937780]

42. Chung FZ, Wu LH, Tian Y, Vartanian MA, Lee H, Bikker J, Humblet C, Pritchard MC, Raphy J and SumanChauhan N. (1995) Two classes of structurally different antagonists display similar species preference for the human tachykinin neurokinin3 receptor. Mol. Pharmacol. 48: 711-6 [PMID:7476898]

43. Chung FZ, Wu LH, Vartanian MA, Watling KJ, Guard S, Woodruff GN and Oxender DL. (1994) The nonpeptide tachykinin NK2 receptor antagonist SR 48968 interacts with human, but not rat, cloned tachykinin NK3 receptors. Biochem. Biophys. Res. Commun. 198: 967-72 [PMID:8117304]

44. Cialdai C, Tramontana M, Patacchini R, Lecci A, Catalani C, Catalioto RM, Meini S, Valenti C, Altamura M and Giuliani S et al.. (2006) MEN15596, a novel nonpeptide tachykinin NK2 receptor antagonist.Eur. J. Pharmacol. 549: 140-8 [PMID:16979621]

45. Ciccocioppo R, Panocka I, Polidori C, De Caro G, Regoli D and Massi M. (1997) Stimulation of tachykinin NK-3 receptors in the nucleus basalis magnocellularis reduces alcohol intake in rats. Peptides 18: $1349-55$ [PMID:9392836]

46. Ciccocioppo R, Panocka I, Polidori C, Froldi R, Angeletti S and Massi M. (1998) Mechanism of action for reduction of ethanol intake in rats by the tachykinin NK-3 receptor agonist aminosenktide. Pharmacol. Biochem. Behav. 61: 459-64 [PMID:9802842]

47. Ciccocioppo R, Panocka I, Pompei P, De Caro G and Massi M. (1994) Selective agonists at NK3 tachykinin receptors inhibit alcohol intake in Sardinian alcohol-preferring rats. Brain Res. Bull. 33: 71-7 [PMID:7506113]

48. Cohen PA, Gower AC, Stucchi AF, Leeman SE, Becker JM and Reed KL. (2007) A neurokinin-1 receptor antagonist that reduces intraabdominal adhesion formation increases peritoneal matrix metalloproteinase activity. Wound Repair Regen 15: 800-8 [PMID:18028127]

49. Corrigan F, Leonard A, Ghabriel M, Van Den Heuvel C and Vink R. (2012) A substance P antagonist improves outcome in female Sprague Dawley rats following diffuse traumatic brain injury. CNS Neurosci Ther 18: 513-5 [PMID:22672307] 
50. Costa SK, Starr A, Hyslop S, Gilmore D and Brain SD. (2006) How important are NK(1) receptors for influencing microvascular inflammation and itch in the skin? Studies using Phoneutria nigriventer venom. Vascul Pharmacol 45: 209-214 [PMID:16914387]

51. Cottrell GS, Padilla B, Pikios S, Roosterman D, Steinhoff M, Gehringer D, Grady EF and Bunnett NW. (2006) Ubiquitin-dependent down-regulation of the neurokinin-1 receptor. J. Biol. Chem. 281: 27773-83 [PMID:16849335]

52. Couture R, Picard P, Poulat $P$ and Prat A. (1995) Characterization of the tachykinin receptors involved in spinal and supraspinal cardiovascular regulation. Can. J. Physiol. Pharmacol. 73: 892-902 [PMID:8846427]

53. Croci T, Aureggi G, Manara L, Emonds-Alt X, Le Fur G, Maffrand JP, Mukenge S and Ferla G. (1998) In vitro characterization of tachykinin NK2-receptors modulating motor responses of human colonic muscle strips. Br. J. Pharmacol. 124: 1321-7 [PMID:9720807]

54. Cunin P, Caillon A, Corvaisier M, Garo E, Scotet M, Blanchard S, Delneste Y and Jeannin P. (2011) The tachykinins substance $P$ and hemokinin- 1 favor the generation of human memory Th17 cells by inducing IL-1 $\beta$, IL-23, and TNF-like 1A expression by monocytes. J. Immunol. 186: 4175-82 [PMID:21368235]

55. D'Orléans-Juste $P$, Claing A, Télémaque $S$, Warner TD and Regoli D. (1991) Neurokinins produce selective venoconstriction via NK-3 receptors in the rat mesenteric vascular bed. Eur. J. Pharmacol. 204: 329-34 [PMID:1723050]

56. D'Orléans-Juste P, Dion S, Drapeau G and Regoli D. (1986) Different receptors are involved in the endothelium-mediated relaxation and the smooth muscle contraction of the rabbit pulmonary artery in response to substance $P$ and related neurokinins. Eur. J. Pharmacol. 125: 37-44 [PMID:2426129]

57. Dai L, Perera DS, King DW, Southwell BR, Burcher E and Liu L. (2012) Hemokinin-1 stimulates prostaglandin $E_{2}$ production in human colon through activation of cyclooxygenase-2 and inhibition of 15 hydroxyprostaglandin dehydrogenase. J. Pharmacol. Exp. Ther. 340: 27-36 [PMID:21957267]

58. Dam TV, Escher E and Quirion R. (1990) Visualization of neurokinin-3 receptor sites in rat brain using the highly selective ligand [3H]senktide. Brain Res. 506: 175-9 [PMID:1689199]

59. Dass NB, Bassil A, Morgan M and Sanger GJ. (2002) Localisation and distribution of functional neurokinin3 (NK3) receptors in human gastrointestinal tract. Gastroenterology 122: (suppl 1)-

60. Dawson LA, Langmead CJ, Dada A, Watson JM, Wu Z, de la Flor R, Jones GA, Cluderay JE, Southam E and Murkitt GS et al.. (2010) In vitro and in vivo comparison of two non-peptide tachykinin NK3 receptor antagonists: Improvements in efficacy achieved through enhanced brain penetration or altered pharmacological characteristics. Eur. J. Pharmacol. 627: 106-14 [PMID:19879867]

61. De Felipe C, Herrero JF, O'Brien JA, Palmer JA, Doyle CA, Smith AJ, Laird JM, Belmonte C, Cervero F and Hunt SP. (1998) Altered nociception, analgesia and aggression in mice lacking the receptor for substance P. Nature 392: 394-7 [PMID:9537323]

62. De Swert KO, Lefebvre RA, Pauwels RA and Joos GF. (2007) Role of the tachykinin NK(1) receptor in mediating contraction to 5-hydroxytryptamine and antigen in the mouse trachea. Pulm Pharmacol Ther20: 588-95 [PMID:16919985]

63. Deal MJ, Hagan RM, Ireland SJ, Jordan CC, McElroy AB, Porter B, Ross BC, Stephens-Smith M and Ward P. (1992) Conformationally constrained tachykinin analogues: potent and highly selective neurokinin NK-2 receptor agonists. J. Med. Chem. 35: 4195-204 [PMID:1331460]

64. Di Fabio R, Griffante C, Alvaro G, Pentassuglia G, Pizzi DA, Donati D, Rossi T, Guercio G, Mattioli M and Cimarosti $Z$ et al.. (2009) Discovery process and pharmacological characterization of 2-(S)-(4-fluoro-2methylphenyl)piperazine-1-carboxylic acid [1-(R)-(3,5-bis-trifluoromethylphenyl)ethyl]methylamide (vestipitant) as a potent, selective, and orally active NK1 receptor antagonist. J. Med. Chem. 52: 3238-47 [PMID:19388677]

65. Donaldson LF, Haskell CA and Hanley MR. (1996) Functional characterization by heterologous expression of a novel cloned tachykinin peptide receptor. Biochem. J. 320 ( Pt 1): 1-5 [PMID:8947459]

66. Drapeau G, Rouissi N, Nantel F, Rhaleb NE, Tousignant C and Regoli D. (1990) Antagonists for the neurokinin NK-3 receptor evaluated in selective receptor systems. Regul. Pept. 31: 125-35 [PMID:2176308] 
67. Duffy RA, Morgan C, Naylor R, Higgins GA, Varty GB, Lachowicz JE and Parker EM. (2012) Rolapitant (SCH 619734): a potent, selective and orally active neurokinin NK1 receptor antagonist with centrallymediated antiemetic effects in ferrets. Pharmacol. Biochem. Behav. 102: 95-100 [PMID:22497992]

68. Duric V and McCarson KE. (2005) Hippocampal neurokinin-1 receptor and brain-derived neurotrophic factor gene expression is decreased in rat models of pain and stress. Neuroscience 133: 999-1006 [PMID:15964488]

69. Eguchi T, Takano Y, Hatae T, Saito R, Nakayama Y, Shigeyoshi Y, Okamura H, Krause JE and Kamiya H. (1996) Antidiuretic action of tachykinin NK-3 receptor in the rat paraventricular nucleus. Brain Res. 743: 49-55 [PMID:9017229]

70. Elliott JM, Carling RW, Chambers M, Chicchi GG, Hutson PH, Jones AB, MacLeod A, Marwood R, Meneses-Lorente $G$ and Mezzogori $E$ et al.. (2006) N',2-diphenylquinoline-4-carbohydrazide based NK3 receptor antagonists. Bioorg. Med. Chem. Lett. 16: 5748-51 [PMID:16950620]

71. Elliott JM, Carling RW, Chicchi GG, Crawforth J, Hutson PH, Jones AB, Kelly S, Marwood R, MenesesLorente G, Mezzogori E, Murray F, Rigby M, Royo I, Russell MG, Shaw D, Sohal B, Tsao KL and Williams B. (2006) N',2-diphenylquinoline-4-carbohydrazide based NK3 receptor antagonists II. Bioorg Med Chem Lett 16: 5752-5756 [PMID:16950617]

72. Elliott PJ, Mason GS, Stephens-Smith M and Hagan RM. (1991) Behavioural and biochemical responses following activation of midbrain dopamine pathways by receptor selective neurokinin agonists. Neuropeptides 19: 119-26 [PMID:1719444]

73. Emonds-Alt X, Advenier C, Cognon C, Croci T, Daoui S, Ducoux JP, Landi M, Naline E, Neliat G and Poncelet M et al.. (1997) Biochemical and pharmacological activities of SR 144190, a new potent nonpeptide tachykinin NK2 receptor antagonist. Neuropeptides 31: 449-58 [PMID:9413022]

74. Emonds-Alt X, Advenier C, Croci T, Manara L, Neliat G, Poncelet M, Proietto V, Santucci V, Soubrié P and Van Broeck D. (1993) SR 48968, a neurokinin A (NK2) receptor antagonist. Regul. Pept. 46: 31-6 [PMID:8210494]

75. Emonds-Alt X, Bichon D, Ducoux JP, Heaulme M, Miloux B, Poncelet M, Proietto V, Van Broeck D, Vilain $P$ and Neliat G. (1995) SR 142801, the first potent non-peptide antagonist of the tachykinin NK3 receptor. Life Sci. 56: PL27-32 [PMID:7830490]

76. Emonds-Alt X, Golliot F, Pointeau P, Le Fur G and Breliere JC. (1993) Characterization of the binding sites of $[3 \mathrm{H}] \mathrm{SR} 48968$, a potent nonpeptide radioligand antagonist of the neurokinin-2 receptor. Biochem. Biophys. Res. Commun. 191: 1172-7 [PMID:7682062]

77. Emonds-Alt X, Proietto V, Steinberg R, Advenier C, Daoui S, Naline E, Gueudet C, Michaud JC, OuryDonat F and Poncelet M et al.. (2002) Biochemical and pharmacological activities of SSR 146977, a new potent nonpeptide tachykinin NK3 receptor antagonist. Can. J. Physiol. Pharmacol. 80: 482-8 [PMID:12056557]

78. Emonds-Alt X, Vilain $P$, Goulaouic $P$, Proietto V, Van Broeck D, Advenier $C$, Naline E, Neliat G, Le Fur G and Brelière JC. (1992) A potent and selective non-peptide antagonist of the neurokinin $A$ (NK2) receptor. Life Sci. 50: PL101-6 [PMID:1313515]

79. Engel MA, Becker C, Reeh PW and Neurath MF. (2011) Role of sensory neurons in colitis: increasing evidence for a neuroimmune link in the gut. Inflamm. Bowel Dis. 17: 1030-3 [PMID:20722067]

80. Eutamene H, Theodorou V, Fioramonti J and Bueno L. (1997) Rectal distention-induced colonic net water secretion in rats involves tachykinins, capsaicin sensory, and vagus nerves. Gastroenterology 112: 1595602 [PMID:9136838]

81. Fioramonti J, Gaultier E, Toulouse M, Sanger GJ and Bueno L. (2003) Intestinal anti-nociceptive behaviour of NK3 receptor antagonism in conscious rats: evidence to support a peripheral mechanism of action. Neurogastroenterol. Motil. 15: 363-9 [PMID:12846724]

82. Fisher AS, Stewart RJ, Yan T, Hunt SP and Stanford SC. (2007) Disruption of noradrenergic transmission and the behavioural response to a novel environment in NK1R-/- mice. Eur. J. Neurosci. 25: 1195-204 [PMID:17331215]

83. Flynn FW. (2005) Intraventricular injections of tachykinin NK3 receptor agonist reduce the gain of the 
baroreflex in unrestrained rats. Exp. Neurol. 193: 118-24 [PMID:15817270]

84. Flynn FW. (2000) Intraventricular injection of tachykinin NK3 receptor agonists suppresses the ingestion of $\mathrm{NaCl}$-associated tastes. Behav. Neurosci. 114: 1223-8 [PMID:11142654]

85. Flynn FW. (2006) Intraventricular injections of tachykinin NK3 receptor agonists suppress the intake of "salty" tastes by sodium deficient rats. Behav. Brain Res. 166: 1-8 [PMID:16154648]

86. Flynn FW and Smith ME. (1998) Lateral ventricular injections of the NK3 agonist senktide affect salt tasteelicited responses. Peptides 19: 319-24 [PMID:9493864]

87. Flynn FW, Smith ME and Bieber SL. (1999) Differential effects of intraventricular injections of tachykinin NK1 and NK3 receptor agonists on normal and sham drinking of $\mathrm{NaCl}$ by sodium-deficient rats. Behav. Neurosci. 113: 776-86 [PMID:10495085]

88. Folkers K, Feng DM, Asano N, Håkanson R, Weisenfeld-Hallin Z and Leander S. (1990) Spantide II, an effective tachykinin antagonist having high potency and negligible neurotoxicity. Proc Natl Acad Sci U S A 87: 4833-4835 [PMID:1693780]

89. Fong TM, Yu H and Strader CD. (1992) Molecular basis for the species selectivity of the neurokinin-1 receptor antagonists CP-96,345 and RP67580. J. Biol. Chem. 267: 25668-71 [PMID:1281470]

90. Foord SM, Bonner TI, Neubig RR, Rosser EM, Pin JP, Davenport AP, Spedding M and Harmar AJ. (2005) International Union of Pharmacology. XLVI. G protein-coupled receptor list. Pharmacol. Rev. 57: 279-88 [PMID:15914470]

91. Francis BE, Swain C, Sabin V and Burns HD. (1994) Radioiodinated L-703,606: a potent, selective antagonist to the human NK1 receptor. Appl Radiat Isot 45: 97-103 [PMID:8287060]

92. Fristad I, Vandevska-Radunovic V, Fjeld K, Wimalawansa SJ and Hals Kvinnsland I. (2003) NK1, NK2, NK3 and CGRP1 receptors identified in rat oral soft tissues, and in bone and dental hard tissue cells. Cell Tissue Res. 311: 383-91 [PMID:12658446]

93. Gardner CJ, Armour DR, Beattie DT, Gale JD, Hawcock AB, Kilpatrick GJ, Twissell DJ and Ward P. (1996) GR205171: a novel antagonist with high affinity for the tachykinin NK1 receptor, and potent broadspectrum anti-emetic activity. Regul. Pept. 65: 45-53 [PMID:8876035]

94. Gaudreau GA and Plourde V. (2003) Role of tachykinin NK1, NK2 and NK3 receptors in the modulation of visceral hypersensitivity in the rat. Neurosci. Lett. 351: 59-62 [PMID:14583381]

95. Gerard NP, Eddy Jr RL, Shows TB and Gerard C. (1990) The human neurokinin A (substance K) receptor. Molecular cloning of the gene, chromosome localization, and isolation of cDNA from tracheal and gastric tissues. J. Biol. Chem. 265: 20455-62 [PMID:2173708]

96. Gerard NP, Garraway LA, Eddy Jr RL, Shows TB, lijima H, Paquet JL and Gerard C. (1991) Human substance $P$ receptor (NK-1): organization of the gene, chromosome localization, and functional expression of cDNA clones. Biochemistry 30: 10640-6 [PMID:1657150]

97. Gether U, Marray T, Schwartz TW and Johansen TE. (1992) Stable expression of high affinity NK1 (substance $\mathrm{P}$ ) and NK2 (neurokinin A) receptors but low affinity NK3 (neurokinin B) receptors in transfected CHO cells. FEBS Lett. 296: 241-4 [PMID:1311270]

98. Giannotti D, Perrotta E, Di Bugno C, Nannicini R, Harmat NJ, Giolitti A, Patacchini R, Renzetti AR, Rotondaro $L$ and Giuliani S et al.. (2000) Discovery of potent cyclic pseudopeptide human tachykinin NK-2 receptor antagonists. J. Med. Chem. 43: 4041-4 [PMID:11063600]

99. Giardina GA, Sarau HM, Farina C, Medhurst AD, Grugni M, Foley JJ, Raveglia LF, Schmidt DB, Rigolio R and Vassallo $\mathrm{M}$ et al.. (1996) 2-Phenyl-4-quinolinecarboxamides: a novel class of potent and selective non-peptide competitive antagonists for the human neurokinin-3 receptor. J. Med. Chem. 39: 2281-4 [PMID:8691422]

100. Gillespie E, Leeman SE, Watts LA, Coukos JA, O'Brien MJ, Cerda SR, Farraye FA, Stucchi AF and Becker JM. (2011) Truncated neurokinin-1 receptor is increased in colonic epithelial cells from patients with colitisassociated cancer. Proc. Natl. Acad. Sci. U.S.A. 108: 17420-5 [PMID:21969570]

101. Gitter BD, Bruns RF, Howbert JJ, Waters DC, Threlkeld PG, Cox LM, Nixon JA, Lobb KL, Mason NR and Stengel PW. (1995) Pharmacological characterization of LY303870: a novel, potent and selective nonpeptide substance $\mathrm{P}$ (neurokinin-1) receptor antagonist. J. Pharmacol. Exp. Ther. 275: 737-44 
[PMID:7473161]

102. Gitter BD, Regoli D, Howbert JJ, Glasebrook AL and Waters DC. (1994) Interleukin-6 secretion from human astrocytoma cells induced by substance P. J. Neuroimmunol. 51: 101-8 [PMID:7512575]

103. Giuliani S, Barbanti G, Turini D, Quartara L, Rovero P, Giachetti A and Maggi CA. (1991) NK2 tachykinin receptors and contraction of circular muscle of the human colon: characterization of the NK2 receptor subtype. Eur. J. Pharmacol. 203: 365-70 [PMID:1723045]

104. Giuliani S, Patacchini R, Giachetti A and Maggi CA. (1993) In vivo and in vitro activity of SR 48,968, a nonpeptide tachykinin NK-2 receptor antagonist. Regul. Pept. 46: 314-6 [PMID:7692525]

105. Giuliani S, Tramontana M, Lecci A and Maggi CA. (1996) Tachykinin receptors mediate atropine-resistant rat duodenal reflex contractions in vivo. Naunyn Schmiedebergs Arch. Pharmacol. 354: 327-35 [PMID:8878063]

106. Glowinski J, Kemel ML, Desban M, Gauchy C, Lavielle S, Chassaing G, Beaujouan JC and Tremblay L. (1993) Distinct presynaptic control of dopamine release in striosomal- and matrix-enriched areas of the rat striatum by selective agonists of NK1, NK2 and NK3 tachykinin receptors. Regul. Pept. 46: 124-8 [PMID:7692480]

107. Gonzalez A and Sarna SK. (2001) Neural regulation of in vitro giant contractions in the rat colon Am. J. Physiol. Gastrointest. Liver Physiol. 281: G275-82 [PMID:11408281]

108. Goode T, O'Connell J, Anton P, Wong H, Reeve J, O'Sullivan GC, Collins JK and Shanahan F. (2000) Neurokinin-1 receptor expression in inflammatory bowel disease: molecular quantitation and localisation. Gut 47: 387-96 [PMID:10940277]

109. Grady EF, Baluk P, Böhm S, Gamp PD, Wong H, Payan DG, Ansel J, Portbury AL, Furness JB and McDonald DM et al.. (1996) Characterization of antisera specific to NK1, NK2, and NK3 neurokinin receptors and their utilization to localize receptors in the rat gastrointestinal tract. J. Neurosci. 16: 6975-86 [PMID:8824334]

110. Greeno EW, Mantyh P, Vercellotti GM and Moldow CF. (1993) Functional neurokinin 1 receptors for substance $P$ are expressed by human vascular endothelium. J. Exp. Med. 177: 1269-76 [PMID:7683033]

111. Griffond B, Ciofi $P$, Bayer L, Jacquemard $C$ and Fellmann D. (1997) Immunocytochemical detection of the neurokinin $\mathrm{B}$ receptor (NK3) on melanin-concentrating hormone $(\mathrm{MCH})$ neurons in rat brain. J. Chem. Neuroanat. 12: 183-9 [PMID:9141650]

112. Grisshammer R, Little J and Aharony D. (1994) Expression of rat NK-2 (neurokinin A) receptor in E. coli. Recept. Channels 2: 295-302 [PMID:7719707]

113. Guard S and Watson SP. (1991) Tachykinin receptor types: Classification and membrane signalling mechanisms. Neurochem. Int. 18: 149-65 [PMID:20504688]

114. Guard S, Watson SP, Maggio JE, Too HP and Watling KJ. (1990) Pharmacological analysis of [3H]senktide binding to NK3 tachykinin receptors in guinea-pig ileum longitudinal muscle-myenteric plexus and cerebral cortex membranes. Br. J. Pharmacol. 99: 767-73 [PMID:1694464]

115. Guo JZ, Yoshioka K and Otsuka M. (1998) Effects of a tachykinin NK3 receptor antagonist, SR 142801 , studied in isolated neonatal rat spinal cord. Neuropeptides 32: 537-42 [PMID:9920451]

116. Hafidi A, Beurg M, Bouleau Y and Dulon D. (2002) Comparative distribution of NK1, NK2, and NK3 receptors in the rat brainstem auditory nuclei. Brain Res. 947: 299-306 [PMID:12176174]

117. Hagan RM, Beresford IJ, Stables J, Dupere J, Stubbs CM, Elliott PJ, Sheldrick RL, Chollet A, Kawashima $E$ and McElroy $A B$ et al.. (1993) Characterisation, CNS distribution and function of NK2 receptors studied using potent NK2 receptor antagonists. Regul. Pept. 46: 9-19 [PMID:8210508]

118. Hale JJ, Mills SG, MacCoss M, Dorn CP, Finke PE, Budhu RJ, Reamer RA, Huskey SE, Luffer-Atlas D and Dean BJ et al.. (2000) Phosphorylated morpholine acetal human neurokinin-1 receptor antagonists as water-soluble prodrugs. J. Med. Chem. 43: 1234-41 [PMID:10737756]

119. Hale JJ, Mills SG, MacCoss M, Finke PE, Cascieri MA, Sadowski S, Ber E, Chicchi GG, Kurtz M and Metzger J et al.. (1998) Structural optimization affording 2-(R)-(1-(R)-3, 5-bis(trifluoromethyl)phenylethoxy)3-(S)-(4-fluoro)phenyl-4- (3-oxo-1,2,4-triazol-5-yl)methylmorpholine, a potent, orally active, long-acting morpholine acetal human NK-1 receptor antagonist. J. Med. Chem. 41: 4607-14 [PMID:9804700] 
120. Harrison TA, Hoover DB and King MS. (2004) Distinct regional distributions of NK1 and NK3 neurokinin receptor immunoreactivity in rat brainstem gustatory centers. Brain Res. Bull. 63: 7-17 [PMID:15121234]

121. Hastrup $H$ and Schwartz TW. (1996) Septide and neurokinin A are high-affinity ligands on the NK-1 receptor: evidence from homologous versus heterologous binding analysis. FEBS Lett 399: 264-266 [PMID:8985159]

122. Hay DW, Giardina GA, Griswold DE, Underwood DC, Kotzer CJ, Bush B, Potts W, Sandhu P, Lundberg D and Foley JJ et al.. (2002) Nonpeptide tachykinin receptor antagonists. III. SB 235375, a low central nervous system-penetrant, potent and selective neurokinin-3 receptor antagonist, inhibits citric acidinduced cough and airways hyper-reactivity in guinea pigs. J. Pharmacol. Exp. Ther. 300: 314-23 [PMID:11752131]

123. Hershey AD, Dykema PE and Krause JE. (1991) Organization, structure, and expression of the gene encoding the rat substance $P$ receptor. J. Biol. Chem. 266: 4366-74 [PMID:1705552]

124. Hiramoto M, Aizawa S, Iwase O, Nakano M, Toyama K, Hoque M, Nabeshima R, Kaidow A, Imai T and Hoshi $\mathrm{H}$ et al.. (1998) Stimulatory effects of substance $\mathrm{P}$ on CD34 positive cell proliferation and differentiation in vitro are mediated by the modulation of stromal cell function. Int. J. Mol. Med. 1: 347-54 [PMID:9852236]

125. Ho WZ, Lai JP, Zhu XH, Uvaydova M and Douglas SD. (1997) Human monocytes and macrophages express substance $P$ and neurokinin-1 receptor. J. Immunol. 159: 5654-60 [PMID:9548509]

126. Hoffmann T, Bös M, Stadler H, Schnider P, Hunkeler W, Godel T, Galley G, Ballard TM, Higgins GA and Poli SM et al.. (2006) Design and synthesis of a novel, achiral class of highly potent and selective, orally active neurokinin-1 receptor antagonists. Bioorg. Med. Chem. Lett. 16: 1362-5 [PMID:16332435]

127. Huang RR, Cheung AH, Mazina KE, Strader CD and Fong TM. (1992) cDNA sequence and heterologous expression of the human neurokinin-3 receptor. Biochem. Biophys. Res. Commun. 184: 966-72 [PMID:1374246]

128. Huang SC and Korlipara VL. (2010) Neurokinin-1 receptor antagonists: a comprehensive patent survey. Expert Opin Ther Pat 20: 1019-45 [PMID:20533894]

129. Huang WQ, Wang JG, Chen L, Wei HJ and Chen H. (2010) SR140333 counteracts NK-1 mediated cell proliferation in human breast cancer cell line T47D. J. Exp. Clin. Cancer Res. 29: 55 [PMID:20497542]

130. Huber O, Bertrand C, Bunnett NW, Pellegrini CA, Nadel JA, Debas HT and Geppetti P. (1993) Tachykinins contract the circular muscle of the human esophageal body in vitro via NK2 receptors. Gastroenterology 105: 981-7 [PMID:7691676]

131. Huber O, Bertrand C, Bunnett NW, Pellegrini CA, Nadel JA, Nakazato P, Debas HT and Geppetti P. (1993) Tachykinins mediate contraction of the human lower esophageal sphincter in vitro via activation of NK2 receptors. Eur. J. Pharmacol. 239: 103-9 [PMID:8223885]

132. Håkanson R, Leander S, Asano N, Feng DM and Folkers K. (1990) Spantide II, a novel tachykinin antagonist having high potency and low histamine-releasing effect. Regul. Pept. 31: 75-82 [PMID:1702895]

133. Ichinose M, Miura M, Yamauchi H, Kageyama N, Tomaki M, Oyake T, Ohuchi Y, Hida W, Miki H and Tamura $\mathrm{G}$ et al.. (1996) A neurokinin 1-receptor antagonist improves exercise-induced airway narrowing in asthmatic patients. Am. J. Respir. Crit. Care Med. 153: 936-41 [PMID:8630576]

134. Improta $G$ and Broccardo M. (1991) Inhibitory role on gastric secretion of a central NK-3 tachykinin receptor agonist, senktide. Peptides 12: 1433-4 [PMID:1726124]

135. Improta G, Carpino F, Petrozza V, Guglietta A, Tabacco A and Broccardo M. (2003) Central effects of selective NK1 and NK3 tachykinin receptor agonists on two models of experimentally-induced colitis in rats. Peptides 24: 903-11 [PMID:12948843]

136. Inoue H, Nagata $\mathrm{N}$ and Koshihara $\mathrm{Y}$. (1996) Involvement of tachykinin receptors in oedema formation and plasma extravasation induced by substance $\mathrm{P}$, neurokinin $\mathrm{A}$, and neurokinin B in mouse ear. Inflamm. Res. 45: 316-23 [PMID:8841832]

137. Iwabuchi $Y$, Aoki $C$ and Masuhara T. (1989) Effects of tachykinins on the secretion of fluid and glycoproteins from the submandibular glands of rat, mouse, hamster and guinea pig. Jpn. J. Pharmacol. 51: 428-31 [PMID:2482911] 
138. Jiang J, Bunda JL, Doss GA, Chicchi GG, Kurtz MM, Tsao KL, Tong X, Zheng S, Upthagrove A and Samuel K et al.. (2009) Potent, brain-penetrant, hydroisoindoline-based human neurokinin-1 receptor antagonists. J. Med. Chem. 52: 3039-46 [PMID:19354254]

139. Johnson BJ, Brubaker JR, Roehrig JT and Trent DW. (1990) Variants of Venezuelan equine encephalitis virus that resist neutralization define a domain of the E2 glycoprotein. Virology 177: 676-83

[PMID:1695412]

140. Joos GF, Van Schoor J, Kips JC and Pauwels RA. (1996) The effect of inhaled FK224, a tachykinin NK-1 and NK-2 receptor antagonist, on neurokinin A-induced bronchoconstriction in asthmatics. Am J Respir Crit Care Med 153: 1781-1784 [PMID:8665034]

141. Kamali F. (2001) Osanetant Sanofi-Synthélabo. Curr Opin Investig Drugs 2: 950-6 [PMID:11757797]

142. Kamp EH, Beck DR and Gebhart GF. (2001) Combinations of neurokinin receptor antagonists reduce visceral hyperalgesia. J. Pharmacol. Exp. Ther. 299: 105-13 [PMID:11561069]

143. Katayama I and Nishioka K. (1997) Substance P augments fibrogenic cytokine-induced fibroblast proliferation: possible involvement of neuropeptide in tissue fibrosis. J. Dermatol. Sci. 15: 201-6 [PMID:9302648]

144. Keeble J, Blades M, Pitzalis C, Castro da Rocha FA and Brain SD. (2005) The role of substance P in microvascular responses in murine joint inflammation. Br. J. Pharmacol. 144: 1059-66 [PMID:15700029]

145. Keegan KD, Woodruff GN and Pinnock RD. (1992) The selective NK3 receptor agonist senktide excites a subpopulation of dopamine-sensitive neurones in the rat substantia nigra pars compacta in vitro. $\mathrm{Br} \mathrm{J}$ Pharmacol 105: 3-5 [PMID:1375857]

146. Kidd BL, Inglis JJ, Vetsika K, Hood VC, De Felipe C, Bester H, Hunt SP and Cruwys SC. (2003) Inhibition of inflammation and hyperalgesia in NK-1 receptor knock-out mice. Neuroreport 14: 2189-92 [PMID:14625445]

147. Koon HW, Shih D, Karagiannides I, Zhao D, Fazelbhoy Z, Hing T, Xu H, Lu B, Gerard N and Pothoulakis C. (2010) Substance P modulates colitis-associated fibrosis. Am. J. Pathol. 177: 2300-9 [PMID:20889569]

148. Kramer MS, Cutler N, Feighner J, Shrivastava R, Carman J, Sramek JJ, Reines SA, Liu G, Snavely D and Wyatt-Knowles E et al.. (1998) Distinct mechanism for antidepressant activity by blockade of central substance $P$ receptors. Science 281: 1640-5 [PMID:9733503]

149. Krause JE, Staveteig PT, Mentzer JN, Schmidt SK, Tucker JB, Brodbeck RM, Bu JY and Karpitskiy VV. (1997) Functional expression of a novel human neurokinin-3 receptor homolog that binds [3H]senktide and [125I-MePhe7]neurokinin B, and is responsive to tachykinin peptide agonists. Proc. Natl. Acad. Sci. U.S.A. 94: 310-5 [PMID:8990205]

150. Langlois X, Wintmolders C, te Riele P, Leysen JE and Jurzak M. (2001) Detailed distribution of Neurokinin 3 receptors in the rat, guinea pig and gerbil brain: a comparative autoradiographic study. Neuropharmacology 40: 242-53 [PMID:11114403]

151. Laniyonu A, Sliwinski-Lis E and Fleming N. (1988) Different tachykinin receptor subtypes are coupled to the phosphoinositide or cyclic AMP signal transduction pathways in rat submandibular cells. FEBS Lett.

240: 186-90 [PMID:2461321]

152. Laufer R, Gilon C, Chorev M and Selinger Z. (1986) Characterization of a neurokinin B receptor site in rat brain using a highly selective radioligand. J. Biol. Chem. 261: 10257-63 [PMID:2426259]

153. Lecci A, Capriati A, Altamura M and Maggi CA. (2006) Tachykinins and tachykinin receptors in the gut, with special reference to NK2 receptors in human. Auton Neurosci 126-127: 232-49 [PMID:16616700]

154. Lecci A, Giuliani S and Maggi CA. (1992) Effect of the NK-1 receptor antagonist GR 82,334 on reflexlyinduced bladder contractions. Life Sci. 51: PL277-80 [PMID:1335533]

155. Lecci A, Giuliani S, Patacchini R and Maggi CA. (1993) Evidence against a peripheral role of tachykinins in the initiation of micturition reflex in rats. $J$ Pharmacol Exp Ther 264: 1327-1332 [PMID:8383746]

156. Lecci A, Giuliani S, Tramontana M, Meini S, De Giorgio R and Maggi CA. (1996) In vivo evidence for the involvement of tachykinin NK3 receptors in the hexamethonium-resistant inhibitory transmission in the rat colon. Naunyn Schmiedebergs Arch. Pharmacol. 353: 671-9 [PMID:8738300]

157. Lecci A, Giuliani S, Tramontana M, Meini S, Santicioli P and Maggi CA. (2000) Tachykinin-mediated effect 
of nociceptin in the rat urinary bladder in vivo. Eur. J. Pharmacol. 389: 99-102 [PMID:10686301]

158. Lecci A, Tramontana M, Giuliani S and Maggi CA. (1997) Role of tachykinin NK1 and NK2 receptors on colonic motility in anesthetized rats: effect of agonists. Can. J. Physiol. Pharmacol. 75: 582-6 [PMID:9276132]

159. Lessard A, Campos MM, Neugebauer W and Couture R. (2003) Implication of nigral tachykinin NK3 receptors in the maintenance of hypertension in spontaneously hypertensive rats: a pharmacologic and autoradiographic study. Br. J. Pharmacol. 138: 554-63 [PMID:12598409]

160. Lessard A, Laurin M, Yamaguchi $N$ and Couture R. (2004) Central anti-hypertensive effect of tachykinin NK3 receptor antagonists in rat. Eur. J. Pharmacol. 486: 75-83 [PMID:14751411]

161. Liminga U, Johansson PE and Gunne L. (1991) Intranigral tachykinin NK3 receptor agonist elicits oral movements in rats. Pharmacol. Biochem. Behav. 38: 617-20 [PMID:1712496]

162. Linari G, Improta G, Agostini S, Andreassi A and Broccardo M. (2004) Stimulatory effect of PG-KII, an NK3 tachykinin receptor agonist, on isolated pancreatic acini: species-related differences. Peptides 25: 45-51 [PMID:15003355]

163. Liu L, Markus I, Saghire HE, Perera DS, King DW and Burcher E. (2011) Distinct differences in tachykinin gene expression in ulcerative colitis, Crohn's disease and diverticular disease: a role for hemokinin-1? Neurogastroenterol. Motil. 23: 475-83, e179-80 [PMID:21342363]

164. Lördal M, Bränström R and Hellström PM. (1998) Mediation of irregular spiking activity by multiple neurokinin-receptors in the small intestine of the rat. Br. J. Pharmacol. 123: 63-70 [PMID:9484855]

165. Maggi CA and Giuliani S. (1996) Evidence that tachykinin NK2 receptors modulate resting tone in the rat isolated small intestine. Br. J. Pharmacol. 118: 1262-8 [PMID:8818352]

166. Maggi CA, Giuliani S, Santicioli P, Abelli $L$ and Giachetti A. (1991) Facilitation of reflex micturition by intravesical administration of [beta Ala8]-neurokinin A (4-10), a selective NK-2 tachykinin receptor agonist. J. Urol. 145: 184-7 [PMID:1845772]

167. Magraner J, Pinto FM, Anselmi E, Hernandez M, Perez-Afonso R, Martín JD, Advenier C and Candenas ML. (1998) Characterization of tachykinin receptors in the uterus of the oestrogen-primed rat. Br. J. Pharmacol. 123: 259-68 [PMID:9489614]

168. Mann PT, Southwell BR, Ding YQ, Shigemoto R, Mizuno N and Furness JB. (1997) Localisation of neurokinin 3 (NK3) receptor immunoreactivity in the rat gastrointestinal tract. Cell Tissue Res. 289: 1-9 [PMID:9182595]

169. Manzini S, Conti S, Maggi CA, Rovero P and Ballati L. (1988) Neurokinin A-(4-10): a potent bronchospastic agent virtually devoid of sialologic properties in anaesthetized guinea-pigs. Eur. J. Pharmacol. 148: 475-8 [PMID:2454832]

170. Marchetti $C$ and Nistri A. (2001) Neuronal bursting induced by NK3 receptor activation in the neonatal rat spinal cord in vitro. J. Neurophysiol. 86: 2939-50 [PMID:11731550]

171. Martin CA, Naline E, Emonds-Alt X and Advenier C. (1992) Influence of (+/-)-CP-96,345 and SR 48968 on electrical field stimulation of the isolated guinea-pig main bronchus. Eur. J. Pharmacol. 224: 137-43 [PMID:1334836]

172. Martini L, Hastrup H, Holst B, Fraile-Ramos A, Marsh M and Schwartz TW. (2002) NK1 receptor fused to beta-arrestin displays a single-component, high-affinity molecular phenotype. Mol. Pharmacol. 62: 30-7 [PMID:12065752]

173. Massillon D, Chen W, Hawkins M, Liu R, Barzilai N and Rossetti L. (1995) Quantitation of hepatic glucose fluxes and pathways of hepatic glycogen synthesis in conscious mice. Am. J. Physiol. 269: E1037-43 [PMID:8572194]

174. Mastrangelo D, Mathison R, Huggel HJ, Dion S, D'Orléans-Juste P, Rhaleb NE, Drapeau G, Rovero P and Regoli D. (1987) The rat isolated portal vein: a preparation sensitive to neurokinins, particularly neurokinin B. Eur. J. Pharmacol. 134: 321-6 [PMID:3471518]

175. Matuszek MA, Zeng XP, Strigas J and Burcher E. (1998) An investigation of tachykinin NK2 receptor subtypes in the rat. Eur. J. Pharmacol. 352: 103-9 [PMID:9718274]

176. Mau SE, Larsen PJ, Mikkelsen JA and Saermark T. (1990) Substance P and related tachykinins induce 
receptor-mediated hydrolysis of polyphosphoinositides in the rat anterior pituitary. Mol. Cell. Endocrinol. 69: 69-78 [PMID:1691115]

177. Mayordomo C, García-Recio S, Ametller E, Fernández-Nogueira P, Pastor-Arroyo EM, Vinyals L, Casas I, Gascón P and Almendro V. (2012) Targeting of substance P induces cancer cell death and decreases the steady state of EGFR and Her2. J. Cell. Physiol. 227: 1358-66 [PMID:21604273]

178. Megens AA, Ashton D, Vermeire JC, Vermote PC, Hens KA, Hillen LC, Fransen JF, Mahieu M, Heylen L and Leysen JE et al.. (2002) Pharmacological profile of (2R-trans)-4-[1-[3,5-bis(trifluoromethyl)benzoyl]-2(phenylmethyl)-4-piperidinyl]-N-(2,6-dimethylphenyl)-1-acetamide (S)-Hydroxybutanedioate (R116301), an orally and centrally active neurokinin-1 receptor antagonist. J. Pharmacol. Exp. Ther. 302: 696-709 [PMID:12130734]

179. Menzies JR, McKee R and Corbett AD. (2001) Differential alterations in tachykinin NK2 receptors in isolated colonic circular smooth muscle in inflammatory bowel disease and idiopathic chronic constipation. Regul. Pept. 99: 151-6 [PMID:11384776]

180. Mileusnic D, Lee JM, Magnuson DJ, Hejna MJ, Krause JE, Lorens JB and Lorens SA. (1999) Neurokinin-3 receptor distribution in rat and human brain: an immunohistochemical study. Neuroscience 89: 1269-90 [PMID:10362314]

181. Mitolo-Chieppa D, Mansi G, Nacci C, De Salvia MA, Montagnani M, Potenza MA, Rinaldi R, Lerro G, SiroBrigiani $\mathrm{G}$ and Mitolo $\mathrm{Cl}$ et al.. (2001) Idiopathic chronic constipation: tachykinins as cotransmitters in colonic contraction. Eur. J. Clin. Invest. 31: 349-55 [PMID:11298783]

182. Mizuta A, Takano Y, Honda K, Saito R, Matsumoto T and Kamiya H. (1995) Nitric oxide is a mediator of tachykinin NK3 receptor-induced relaxation in rat mesenteric artery. Br. J. Pharmacol. 116: 2919-22 [PMID:8680725]

183. Morcuende S, Gadd CA, Peters M, Moss A, Harris EA, Sheasby A, Fisher AS, De Felipe C, Mantyh PW and Rupniak NM et al.. (2003) Increased neurogenesis and brain-derived neurotrophic factor in neurokinin1 receptor gene knockout mice. Eur. J. Neurosci. 18: 1828-36 [PMID:14622216]

184. Morimoto H, Murai M, Maeda Y, Yamaoka M, Nishikawa M, Kiyotoh S and Fujii T. (1992) FK 224, a novel cyclopeptide substance P antagonist with NK1 and NK2 receptor selectivity. J. Pharmacol. Exp. Ther. 262: 398-402 [PMID:1378096]

185. Mukerji I, Ramkissoon SH, Reddy KK and Rameshwar P. (2005) Autocrine proliferation of neuroblastoma cells is partly mediated through neurokinin receptors: relevance to bone marrow metastasis. $J$. Neurooncol. 71: 91-8 [PMID:15690122]

186. Mulè F, Amato A, Vannucchi MG, Faussone-Pellegrini MS and Serio R. (2006) Role of NK1 and NK2 receptors in mouse gastric mechanical activity. Br. J. Pharmacol. 147: 430-6 [PMID:16402037]

187. Musazzi L, Perez J, Hunt SP, Racagni G and Popoli M. (2005) Changes in signaling pathways regulating neuroplasticity induced by neurokinin 1 receptor knockout. Eur. J. Neurosci. 21: 1370-8 [PMID:15813946]

188. Muñoz M, Rosso M, Casinello F and Coveñas R. (2010) Paravertebral anesthesia: how substance P and the NK-1 receptor could be involved in regional block and breast cancer recurrence. Breast Cancer Res. Treat. 122: 601-3 [PMID:20333544]

189. Nakajima Y, Tsuchida K, Negishi M, Ito S and Nakanishi S. (1992) Direct linkage of three tachykinin receptors to stimulation of both phosphatidylinositol hydrolysis and cyclic AMP cascades in transfected Chinese hamster ovary cells. J. Biol. Chem. 267: 2437-42 [PMID:1370820]

190. Nakayama Y, Takano Y, Saito R and Kamiya H. (1992) Central pressor actions of tachykinin NK-3 receptor in the paraventricular nucleus of the rat hypothalamus. Brain Res. 595: 339-42 [PMID:1281741]

191. Naline E, Höglund CO, Vincent F, Emonds-Alt X, Lagente V, Advenier C and Frossard N. (2007) Role of tachykinin NK3 receptors in the release and effects of nerve growth factor in human isolated bronchi. Eur. J. Pharmacol. 560: 206-11 [PMID:17306250]

192. Natsugari H, Ikeura Y, Kamo I, Ishimaru T, Ishichi Y, Fujishima A, Tanaka T, Kasahara F, Kawada M and Doi T. (1999) Axially chiral 1,7-naphthyridine-6-carboxamide derivatives as orally active tachykinin NK(1) receptor antagonists: synthesis, antagonistic activity, and effects on bladder functions. J Med Chem 42: 3982-93 [PMID:10508446] 
193. Navarro P, Ramkissoon SH, Shah S, Park JM, Murthy RG, Patel SA, Greco SJ and Rameshwar P. (2012) An indirect role for the oncomir-519b in the expression of truncated neurokinin-1 in breast cancer cells. Exp. Cell Res. 318: 2604-15 [PMID:22981979]

194. Nichols ML, Allen BJ, Rogers SD, Ghilardi JR, Honore P, Luger NM, Finke MP, Li J, Lappi DA and Simone DA et al.. (1999) Transmission of chronic nociception by spinal neurons expressing the substance $P$ receptor. Science 286: 1558-61 [PMID:10567262]

195. Norris SK, Boden PR and Woodruff GN. (1993) Agonists selective for tachykinin NK1 and NK3 receptors excite subpopulations of neurons in the rat medial habenula nucleus in vitro. Eur. J. Pharmacol. 234: 223-8 [PMID:7683268]

196. Nsa Allogho S, Nguyen-Le XK, Gobeil F, Pheng LH and Regoli D. (1997) Neurokinin receptors (NK1, NK2) in the mouse: a pharmacological study. Can. J. Physiol. Pharmacol. 75: 552-7 [PMID:9276127]

197. Nénan S, Germain N, Lagente V, Emonds-Alt X, Advenier C and Boichot E. (2001) Inhibition of inflammatory cell recruitment by the tachykinin NK(3)-receptor antagonist, SR 142801, in a murine model of asthma. Eur. J. Pharmacol. 421: 201-5 [PMID:11516437]

198. Oury-Donat F, Carayon P, Thurneyssen O, Pailhon V, Emonds-Alt X, Soubrié P and Le Fur G. (1995) Functional characterization of the nonpeptide neurokinin3 (NK3) receptor antagonist, SR142801 on the human NK3 receptor expressed in Chinese hamster ovary cells. J. Pharmacol. Exp. Ther. 274: 148-54 [PMID:7616392]

199. Pagán B, Isidro AA, Coppola D, Chen Z, Ren Y, Wu J and Appleyard CB. (2010) Effect of a neurokinin-1 receptor antagonist in a rat model of colitis-associated colon cancer. Anticancer Res. 30: 3345-53 [PMID:20944107]

200. Palanche T, llien B, Zoffmann S, Reck MP, Bucher B, Edelstein SJ and Galzi JL. (2001) The neurokinin A receptor activates calcium and CAMP responses through distinct conformational states. J. Biol. Chem. 276: 34853-61 [PMID:11459843]

201. Palea S, Dalforno G, Gaviraghi G, Hagan RM, Trist DG and Pietra C. (1993) Further studies on the effects of selective neurokinin agonists upon the activation of micturition reflex in rats. Evidence for a dual NK-1 receptor mediated excitatory and inhibitory activity. Neuropeptides 24: 285-91 [PMID:7687043]

202. Palma C. (2006) Tachykinins and their receptors in human malignancies.Curr Drug Targets 7: 1043-52 [PMID:16918332]

203. Palmer RM, Ferrige AG and Moncada S. (1987) Nitric oxide release accounts for the biological activity of endothelium-derived relaxing factor. Nature 327: 524-6 [PMID:3495737]

204. Panocka I, Massi M, Lapo I, Swiderski T, Kowalczyk M and Sadowski B. (2001) Antidepressant-type effect of the NK3 tachykinin receptor agonist aminosenktide in mouse lines differing in endogenous opioid system activity. Peptides 22: 1037-42 [PMID:11445231]

205. Pasichnichenko OM and Skok VI. (1999) [The effect of SR 142801, a blocker of tachykinin NK-3 receptors, on synaptic transmission in the rat caudal mesenteric ganglion]. Fiziol Zh 45: 55-60 [PMID:10474803]

206. Patel HJ, Ramkissoon SH, Patel PS and Rameshwar P. (2005) Transformation of breast cells by truncated neurokinin-1 receptor is secondary to activation by preprotachykinin-A peptides. Proc. Natl. Acad. Sci. U.S.A. 102: 17436-41 [PMID:16291810]

207. Piedimonte G, Rodriguez MM, King KA, McLean S and Jiang X. (1999) Respiratory syncytial virus upregulates expression of the substance $\mathrm{P}$ receptor in rat lungs. Am. J. Physiol. 277: L831-40 [PMID:10516226]

208. Pinnock RD, Suman-Chauhan N, Chung FZ, Webdale L, Madden Z, Hill DR and Woodruff GN. (1994) Characterization of tachykinin mediated increases in [Ca2+]i in Chinese hamster ovary cells expressing human tachykinin NK3 receptors. Eur. J. Pharmacol. 269: 73-8 [PMID:7530208]

209. Placenza FM, Fletcher PJ, Vaccarino FJ and Erb S. (2006) Effects of central neurokinin-1 receptor antagonism on cocaine- and opiate-induced locomotor activity and self-administration behaviour in rats. Pharmacol. Biochem. Behav. 84: 94-101 [PMID:16757018]

210. Placenza FM, Vaccarino FJ, Fletcher PJ and Erb S. (2005) Activation of central neurokinin-1 receptors induces reinstatement of cocaine-seeking behavior. Neurosci Lett 390: $42-47$ [PMID:16125318] 
211. Polidori C, Pompei P, Ciccocioppo R, de Caro G and Massi M. (1996) Effects of the selective tachykinin NK3 receptor agonist $\mathrm{NH} 2$-senktide on intraoral intake and taste reactivity responses elicited by $\mathrm{NaCl}$ in sodium-replete rats. Regul. Pept. 66: 101-4 [PMID:8899901]

212. Preston Z, Richardson PJ, Pinnock RD and Lee K. (2000) NK-3 receptors are expressed on mouse striatal gamma-aminobutyric acid-ergic interneurones and evoke $[(3) \mathrm{H}]$ gamma-aminobutyric acid release.

Neurosci. Lett. 284: 89-92 [PMID:10771169]

213. Qian Y, Emonds-Alt X and Advenier C. (1993) Effects of capsaicin, (+/-)-CP-96,345 and SR 48968 on the bradykinin-induced airways microvascular leakage in guinea-pigs. Pulm Pharmacol6: 63-7 [PMID:7682876]

214. Rahman M, Lördal M, al-Saffar A and Hellström PM. (1994) Intestinal motility responses to neuropeptide gamma in vitro and in vivo in the rat: comparison with neurokinin 1 and neurokinin 2 receptor agonists. Acta Physiol. Scand. 151: 497-505 [PMID:7976423]

215. Rameshwar P. (2007) Implication of possible therapies targeted for the tachykinergic system with the biology of neurokinin receptors and emerging related proteins. Recent Pat CNS Drug Discov 2: 79-84 [PMID:18221219]

216. Rameshwar P and Gascón P. (1995) Substance P (SP) mediates production of stem cell factor and interleukin-1 in bone marrow stroma: potential autoregulatory role for these cytokines in SP receptor expression and induction. Blood 86: 482-90 [PMID:7541664]

217. Rameshwar P, Joshi DD, Yadav P, Qian J, Gascon P, Chang VT, Anjaria D, Harrison JS and Song X. (2001) Mimicry between neurokinin-1 and fibronectin may explain the transport and stability of increased substance $\mathrm{P}$ immunoreactivity in patients with bone marrow fibrosis. Blood 97: 3025-31 [PMID:11342427]

218. Rameshwar P, Oh HS, Yook C, Gascon P and Chang VT. (2003) Substance p-fibronectin-cytokine interactions in myeloproliferative disorders with bone marrow fibrosis. Acta Haematol. 109: 1-10 [PMID:12486316]

219. Ramkissoon SH, Patel PS, Taborga M and Rameshwar P. (2007) Nuclear factor-kappaB is central to the expression of truncated neurokinin-1 receptor in breast cancer: implication for breast cancer cell quiescence within bone marrow stroma. Cancer Res. 67: 1653-9 [PMID:17308106]

220. Reddy BY, Greco SJ, Patel PS, Trzaska KA and Rameshwar P. (2009) RE-1-silencing transcription factor shows tumor-suppressor functions and negatively regulates the oncogenic TAC1 in breast cancer cells. Proc. Natl. Acad. Sci. U.S.A. 106: 4408-13 [PMID:19246391]

221. Reddy BY, Trzaska KA, Murthy RG, Navarro P and Rameshwar P. (2008) Neurokinin receptors as potential targets in breast cancer treatment. Curr Drug Discov Techno/ 5: 15-9 [PMID:18537563]

222. Reed KL, Fruin AB, Bishop-Bartolomei KK, Gower AC, Nicolaou M, Stucchi AF, Leeman SE and Becker JM. (2002) Neurokinin-1 receptor and substance $P$ messenger RNA levels increase during intraabdominal adhesion formation. J. Surg. Res. 108: 165-72 [PMID:12443729]

223. Reed KL, Fruin AB, Gower AC, Stucchi AF, Leeman SE and Becker JM. (2004) A neurokinin 1 receptor antagonist decreases postoperative peritoneal adhesion formation and increases peritoneal fibrinolytic activity. Proc. Natl. Acad. Sci. U.S.A. 101: 9115-20 [PMID:15187234]

224. Regoli D, Boudon A and Fauchére JL. (1994) Receptors and antagonists for substance P and related peptides. Pharmacol. Rev. 46: 551-99 [PMID:7534932]

225. Ribeiro SJ, Teixeira RM, Calixto JB and De Lima TC. (1999) Tachykinin NK(3)receptor involvement in anxiety. Neuropeptides 33: 181-188 [PMID:10657489]

226. Roush ED and Kwatra MM. (1998) Human substance $P$ receptor expressed in Chinese hamster ovary cells directly activates $\mathrm{G}($ alpha q/11), G(alpha s), G(alpha o). FEBS Lett. 428: 291-4 [PMID:9654151]

227. Rumsey WL, Aharony D, Bialecki RA, Abbott BM, Barthlow HG, Caccese R, Ghanekar S, Lengel D, McCarthy M and Wenrich B et al.. (2001) Pharmacological characterization of ZD6021: a novel, orally active antagonist of the tachykinin receptors. J. Pharmacol. Exp. Ther. 298: 307-15 [PMID:11408556]

228. Rupniak NM, Carlson EJ, Webb JK, Harrison T, Porsolt RD, Roux S, de Felipe C, Hunt SP, Oates B and Wheeldon A. (2001) Comparison of the phenotype of NK1R-/- mice with pharmacological blockade of the substance P (NK1 ) receptor in assays for antidepressant and anxiolytic drugs. Behav Pharmacol 12: 497- 
508 [PMID:11742144]

229. Saban R, Saban MR, Nguyen NB, Lu B, Gerard C, Gerard NP and Hammond TG. (2000) Neurokinin-1 (NK-1) receptor is required in antigen-induced cystitis. Am. J. Pathol. 156: 775-80 [PMID:10702392]

230. Saffroy M, Torrens $Y$, Glowinski J and Beaujouan JC. (2003) Autoradiographic distribution of tachykinin NK2 binding sites in the rat brain: comparison with NK1 and NK3 binding sites. Neuroscience 116: 761-73 [PMID:12573718]

231. Saigo A, Takano Y, Matsumoto T, Tran M, Nakayama Y, Saito R, Yamada K and Kamiya H. (1993) Central administration of senktide, a tachykinin NK-3 agonist, has an antidiuretic action by stimulating AVP release in water-loaded rats. Neurosci. Lett. 159: 187-90 [PMID:7505413]

232. Sakurada T, Tan-No K, Yamada T, Sakurada S, Kisara K, Ohba M and Terenius L. (1990) N-terminal substance $P$ fragments inhibit the spinally induced, NK 1 receptor mediated behavioural responses in mice. Life Sci. 47: PL109-13 [PMID:1701844]

233. Sakurada T, Yamada T, Sakurada S, Kisara K and Ohba M. (1989) Substance P analogues containing Dhistidine antagonize the behavioural effects of intrathecally co-administered substance $P$ in mice. Eur. J. Pharmacol. 174: 153-60 [PMID:2483548]

234. Sakurada T, Yamada T, Tan-no K, Manome Y, Sakurada S, Kisara K and Ohba M. (1991) Differential effects of substance $P$ analogs on neurokinin 1 receptor agonists in the mouse spinal cord. $J$ Pharmacol Exp Ther 259: 205-210 [PMID:1717679]

235. Sandoval-Guzmán T and Rance NE. (2004) Central injection of senktide, an NK3 receptor agonist, or neuropeptide $\mathrm{Y}$ inhibits $\mathrm{LH}$ secretion and induces different patterns of Fos expression in the rat hypothalamus. Brain Res. 1026: 307-12 [PMID:15488494]

236. Sarau HM, Feild JA, Ames RS, Foley JJ, Nuthulaganti P, Schmidt DB, Buckley PT, Elshourbagy NA, Brawner ME and Luttmann MA et al.. (2001) Molecular and pharmacological characterization of the murine tachykinin NK(3) receptor. Eur. J. Pharmacol. 413: 143-50 [PMID:11226387]

237. Sarau HM, Griswold DE, Bush B, Potts W, Sandhu P, Lundberg D, Foley JJ, Schmidt DB, Webb EF and Martin LD et al.. (2000) Nonpeptide tachykinin receptor antagonists. II. Pharmacological and pharmacokinetic profile of SB-222200, a central nervous system penetrant, potent and selective NK-3 receptor antagonist. J. Pharmacol. Exp. Ther. 295: 373-81 [PMID:10992004]

238. Sarau HM, Griswold DE, Potts W, Foley JJ, Schmidt DB, Webb EF, Martin LD, Brawner ME, Elshourbagy NA and Medhurst AD et al.. (1997) Nonpeptide tachykinin receptor antagonists: I. Pharmacological and pharmacokinetic characterization of SB 223412, a novel, potent and selective neurokinin-3 receptor antagonist. J. Pharmacol. Exp. Ther. 281: 1303-11 [PMID:9190866]

239. Sasai $Y$ and Nakanishi S. (1989) Molecular characterization of rat substance $K$ receptor and its mRNAs. Biochem. Biophys. Res. Commun. 165: 695-702 [PMID:2480781]

240. Schmid G, Carità F, Bonanno G and Raiteri M. (1998) NK-3 receptors mediate enhancement of substance $\mathrm{P}$ release from capsaicin-sensitive spinal cord afferent terminals. Br. J. Pharmacol. 125: 621-6 [PMID:9831894]

241. Schoborg RV, Hoover DB, Tompkins JD and Hancock JC. (2000) Increased ganglionic responses to substance $\mathrm{P}$ in hypertensive rats due to upregulation of NK(1) receptors. Am. J. Physiol. Regul. Integr. Comp. Physiol. 279: R1685-94 [PMID:11049850]

242. Schöppe J, Ehrenmann J, Klenk C, Rucktooa P, Schütz M, Doré AS and Plückthun A. (2019) Crystal structures of the human neurokinin 1 receptor in complex with clinically used antagonists. Nat Commun 10: 17 [PMID:30604743]

243. Serio R, Mulè F, Bonvissuto F and Postorino A. (1998) Tachykinins mediate noncholinergic excitatory neural responses in the circular muscle of rat proximal colon. Can. J. Physiol. Pharmacol. 76: 684-9 [PMID:9923407]

244. Shafton AD, Bogeski G, Kitchener PD, Lewis VA, Sanger GJ and Furness JB. (2004) Effects of the peripherally acting NK receptor antagonist, SB-235375, on intestinal and somatic nociceptive responses and on intestinal motility in anaesthetized rats. Neurogastroenterol. Motil. 16: 223-31 [PMID:15086876]

245. Shah TU, Liddle R, Branch MS, Jowell P, Obando J and Poleski M. (2012) Pilot study of aprepitant for 
prevention of post-ERCP pancreatitis in high risk patients: a phase II randomized, double-blind placebo controlled trial. JOP 13: 514-8 [PMID:22964958]

246. Sheldrick RL, Ball DI and Coleman RA. (1990) Characterisation of the neurokinin receptors mediating contraction of isolated tracheal preparations from a variety of species. Agents Actions Suppl. 31: 205-9 [PMID:1706905]

247. Shigemoto R, Yokota $Y$, Tsuchida $K$ and Nakanishi S. (1990) Cloning and expression of a rat neuromedin K receptor cDNA. J. Biol. Chem. 265: 623-8 [PMID:2153106]

248. Shughrue PJ, Lane MV and Merchenthaler I. (1996) In situ hybridization analysis of the distribution of neurokinin-3 mRNA in the rat central nervous system. J. Comp. Neurol. 372: 395-414 [PMID:8873868]

249. Simonsen KB, Juhl K, Steiniger-Brach B and Nielsen SM. (2010) Novel NK(3) receptor antagonists for the treatment of schizophrenia and other CNS indications. Curr Opin Drug Discov Devel 13: 379-88 [PMID:20597024]

250. Smith ME and Flynn FW. (1999) Intraventricular injections of tachykinin NK3 receptor agonists affect salt intake. A shift in taste intensity? Ann. N. Y. Acad. Sci. 897: 432-5 [PMID:10676471]

251. Smith PW, Cooper AW, Bell R, Beresford IJ, Gore PM, McElroy AB, Pritchard JM, Saez V, Taylor NR and Sheldrick RL. (1995) New spiropiperidines as potent and selective non-peptide tachykinin NK2 receptor antagonists. J. Med. Chem. 38: 3772-9 [PMID:7562907]

252. Smith PW, Wyman PA, Lovell P, Goodacre C, Serafinowska HT, Vong A, Harrington F, Flynn S, Bradley DM and Porter R et al.. (2009) New quinoline NK3 receptor antagonists with CNS activity.Bioorg. Med. Chem. Lett. 19: 837-40 [PMID:19117759]

253. Stables JM, Beresford IJ, Arkinstall S, Ireland SJ, Walsh DM, Seale PW, Ward P and Hagan RM. (1994) GR138676, a novel peptidic tachykinin antagonist which is potent at NK3 receptors. Neuropeptides 27: 333-41 [PMID:7534879]

254. Stoessl AJ, Brackstone M, Rajakumar N and Gibson CJ. (1995) Pharmacological characterization of grooming induced by a selective NK-1 tachykinin receptor agonist. Brain Res. 700: 115-20 [PMID:8624700]

255. Stoessl AJ, Dourish CT and Iversen SD. (1988) The NK-3 tachykinin receptor agonist senktide elicits 5HT-mediated behaviour following central or peripheral administration in mice and rats. Br. J. Pharmacol. 94: 285-7 [PMID:2456111]

256. Stoessl AJ, Dourish CT and Iversen SD. (1988) The NK-3 tachykinin agonist senktide elicits yawning and chewing mouth movements following subcutaneous administration in the rat. Evidence for cholinergic mediation. Psychopharmacology (Berl.) 95: 502-6 [PMID:2463651]

257. Stoessl AJ, Dourish CT, Young SC, Williams BJ, Iversen SD and Iversen LL. (1987) Senktide, a selective neurokinin B-like agonist, elicits serotonin-mediated behaviour following intracisternal administration in the mouse. Neurosci. Lett. 80: 321-6 [PMID:2446214]

258. Stoess AJ and Hill DR. (1990) Autoradiographic visualization of NK-3 tachykinin binding sites in the rat brain, utilizing [3H]senktide. Brain Res. 534: 1-7 [PMID:1705846]

259. Stoessl AJ, Szczutkowski E, Glenn B and Watson I. (1991) Behavioural effects of selective tachykinin agonists in midbrain dopamine regions. Brain Res. 565: 254-62 [PMID:1668812]

260. Stratowa C, Machat H, Burger E, Himmler A, Schafer R, Spevak W, Weyer U, Wiche-Castanon M and Czernilofsky AP. (1995) Functional characterization of the human neurokinin receptors NK1, NK2, and NK3 based on a cellular assay system. J. Recept. Signal Transduct. Res. 15: 617-30 [PMID:8903968]

261. Sundelin JB, Provvedini DM, Wahlestedt CR, Laurell H, Pohl JS and Peterson PA. (1992) Molecular cloning of the murine substance $K$ and substance $P$ receptor genes. Eur $J$ Biochem 203: 625-631 [PMID:1370937]

262. Takano Y, Nakayama Y, Matsumoto T, Saito R and Kamiya HO. (1993) The mechanism of central pressor actions of tachykinin NK-3 receptor in the paraventricular nucleus of the hypothalamus in rats. Regul. Pept. 46: 360-3 [PMID:7692537]

263. Takeda Y, Chou KB, Takeda J, Sachais BS and Krause JE. (1991) Molecular cloning, structural characterization and functional expression of the human substance $\mathrm{P}$ receptor. Biochem. Biophys. Res. Commun. 179: 1232-40 [PMID:1718267] 
264. Tanabe T, Otani H, Bao L, Mikami Y, Yasukura T, Ninomiya T, Ogawa R and Inagaki C. (1996) Intracellular signaling pathway of substance P-induced superoxide production in human neutrophils. Eur. J. Pharmacol. 299: 187-95 [PMID:8901022]

265. Tian Y, Wu LH, Oxender DL and Chung FZ. (1996) The unpredicted high affinities of a large number of naturally occurring tachykinins for chimeric NK1/NK3 receptors suggest a role for an inhibitory domain in determining receptor specificity. J. Biol. Chem. 271: 20250-7 [PMID:8702757]

266. Tooney PA, Au GG and Chahl LA. (2000) Localisation of tachykinin NK1 and NK3 receptors in the human prefrontal and visual cortex. Neurosci. Lett. 283: 185-8 [PMID:10754218]

267. Tooney PA, Au GG and Chahl LA. (2000) Tachykinin NK1 and NK3 receptors in the prefrontal cortex of the human brain. Clin. Exp. Pharmacol. Physiol. 27: 947-9 [PMID:11071316]

268. Torrens Y, Saffroy M, Glowinski J and Beaujouan JC. (1997) Substance P(6-11) and natural tachykinins interact with septide-sensitive tachykinin receptors coupled to a phospholipase $\mathrm{C}$ in the rat urinary bladder. Neuropeptides 31: 243-51 [PMID:9243521]

269. Tousignant C, Guillemette G, Drapeau G, Télémaque S, Dion S and Regoli D. (1990) 125I-BH[Sar9, Met(O2)11]-SP, a new selective ligand for the NK-1 receptor in the central nervous system. Brain Res. 524: 263-70 [PMID:1705465]

270. Tousignant C, Guillemette $G$ and Regoli D. (1991) Binding sites for [3H][Sar9, Met(O2)11]substance P in rat brain and guinea pig ileum. Brain Res. 560: 1-11 [PMID:1722129]

271. Tremblay L, Kemel ML, Desban M, Gauchy C and Glowinski J. (1992) Distinct presynaptic control of dopamine release in striosomal- and matrix-enriched areas of the rat striatum by selective agonists of NK1, NK2, and NK3 tachykinin receptors. Proc. Natl. Acad. Sci. U.S.A. 89: 11214-8 [PMID:1280822]

272. Trist DG, Ratti E and Bye A. (2013) Why receptor reserve matters for neurokinin1 (NK1) receptor antagonists. J. Recept. Signal Transduct. Res. 33: 333-7 [PMID:24106886]

273. Tsuchiya M, Fujiwara Y, Kanai Y, Mizutani M, Shimada K, Suga O, Ueda S, Watson JW and Nagahisa A. (2002) Anti-emetic activity of the novel nonpeptide tachykinin NK1 receptor antagonist ezlopitant (CJ11,974) against acute and delayed cisplatin-induced emesis in the ferret. Pharmacology 66: 144-52 [PMID:12372904]

274. Tumati S, Largent-Milnes TM, Keresztes AI, Yamamoto T, Vanderah TW, Roeske WR, Hruby VJ and Varga EV. (2012) Tachykinin $\mathrm{NK}_{1}$ receptor antagonist co-administration attenuates opioid withdrawalmediated spinal microglia and astrocyte activation. Eur. J. Pharmacol. 684: 64-70 [PMID:22724132]

275. Unger T, Carolus S, Demmert G, Ganten D, Lang RE, Maser-Gluth C, Steinberg H and Veelken R. (1988) Substance $\mathrm{P}$ induces a cardiovascular defense reaction in the rat: pharmacological characterization. Circ Res 63: 812-820 [PMID:2458861]

276. van Giersbergen PL, Shatzer SA, Burcher E and Buck SH. (1992) Comparison of the effects of neuropeptide $\mathrm{K}$ and neuropeptide gamma with neurokinin $\mathrm{A}$ at NK2 receptors in the hamster urinary bladder. Naunyn Schmiedebergs Arch. Pharmacol. 345: 51-6 [PMID:1311427]

277. Vannucchi MG and Faussone-Pellegrini MS. (2000) NK1, NK2 and NK3 tachykinin receptor localization and tachykinin distribution in the ileum of the mouse. Anat. Embryol. 202: 247-55 [PMID:10994997]

278. Wang H, Zhang YQ, Ding YQ and Zhang JS. (2002) Localization of neurokinin $B$ receptor in mouse gastrointestinal tract. World J Gastroenterol 8: 172-175 [PMID:11833097]

279. Wang $Y$ and Wang $D H$. (2012) Role of substance $P$ in renal injury during DOCA-salt hypertension. Endocrinology 153: 5972-9 [PMID:23024265]

280. Warner FJ, Comis A, Miller RC and Burcher E. (1999) Characterization of the [125I]-neurokinin A binding site in the circular muscle of human colon. Br. J. Pharmacol. 127: 1105-10 [PMID:10455255]

281. Warner FJ, Liu L, Lubowski DZ and Burcher E. (2000) Circular muscle contraction, messenger signalling and localization of binding sites for neurokinin A in human sigmoid colon. Clin. Exp. Pharmacol. Physiol. 27: 928-33 [PMID:11071312]

282. Warner FJ, Mack P, Comis A, Miller RC and Burcher E. (2001) Structure-activity relationships of neurokinin $A(4-10)$ at the human tachykinin $\mathrm{NK}(2)$ receptor: the role of natural residues and their chirality. Biochem. Pharmacol. 61: 55-60 [PMID:11137709] 
283. Watanabe $Y$, Asai $H$, Ishii T, Kiuchi S, Okamoto M, Taniguchi H, Nagasaki M and Saito A. (2008) Pharmacological characterization of T-2328, 2-fluoro-4'-methoxy-3'-[[[(2S,3S)-2-phenyl-3piperidinyl]amino]methyl]-[1,1'-biphenyl]-4-carbonitrile dihydrochloride, as a brain-penetrating antagonist of tachykinin NK1 receptor. J. Pharmacol. Sci. 106: 121-7 [PMID:18187929]

284. Williams R, Zou X and Hoyle GW. (2007) Tachykinin-1 receptor stimulates proinflammatory gene expression in lung epithelial cells through activation of NF-kappaB via a G(q)-dependent pathway. Am. J. Physiol. Lung Cell Mol. Physiol. 292: L430-7 [PMID:17041011]

285. Wormser U, Laufer R, Hart Y, Chorev M, Gilon C and Selinger Z. (1986) Highly selective agonists for substance $\mathrm{P}$ receptor subtypes. EMBO J. 5: 2805-8 [PMID:2431898]

286. Yachnis AT, Crawley JN, Jensen RT, McGrane MM and Moody TW. (1984) The antagonism of bombesin in the CNS by substance $P$ analogues. Life Sci. 35: 1963-9 [PMID:6208451]

287. Yin J, Chapman K, Clark LD, Shao Z, Borek D, Xu Q, Wang J and Rosenbaum DM. (2018) Crystal structure of the human $\mathrm{NK}_{1}$ tachykinin receptor. Proc. Natl. Acad. Sci. U.S.A. 115: 13264-13269 [PMID:30538204]

288. Yoshida A, Mobarakeh JI, Sakurai E, Sakurada S, Orito T, Kuramasu A, Kato M and Yanai K. (2005) Intrathecally-administered histamine facilitates nociception through tachykinin NK1 and histamine H1 receptors: a study in histidine decarboxylase gene knockout mice. Eur. J. Pharmacol. 522: 55-62 [PMID:16212954]

289. Zagorodnyuk V, Santicioli P, Turini D and Maggi CA. (1997) Tachykinin NK1 and NK2 receptors mediate non-adrenergic non-cholinergic excitatory neuromuscular transmission in the human ileum. Neuropeptides 31: 265-71 [PMID:9243524]

290. Zaratin P, Angelici O, Clarke GD, Schmid G, Raiteri M, Carità F and Bonanno G. (2000) NK3 receptor blockade prevents hyperalgesia and the associated spinal cord substance $\mathrm{P}$ release in monoarthritic rats. Neuropharmacology 39: 141-9 [PMID:10665827]

291. Zerari F, Karpitskiy V, Krause J, Descarries L and Couture R. (1997) Immunoelectron microscopic localization of NK-3 receptor in the rat spinal cord. Neuroreport 8: 2661-4 [PMID:9295096] 